\title{
Light scatter characteristics of blast cells in acute myeloid leukaemia: association with morphology and immunophenotype
}

\author{
M B Vidriales, A Orfao, M C López-Berges, M González, A López-Macedo, \\ M A García, J Galende, J F San Miguel
}

\begin{abstract}
Aims-To analyse the forward scatter/side scatter (FSC/SSC) distribution of acute myeloblastic leukaemia (AML) blast cells in order to assess whether it correlates with their morphology, immunophenotype, and clinical and biological disease characteristics.

Methods-FSC/SSC patterns were established upon taking into account the localisation of the residual $T$ lymphocytes in the FSC/SSC dot plot as an internal biological standard. One hundred and seventy one newly diagnosed AML patients were analysed and five different FSC/SSC patterns were established. These five patterns could be grouped into two major categories taking into account the FSC/SSC distribution of normal cells in a bone marrow aspirate: immature patterns (1 and 2 ) and mature patterns (3, 4, and 5). These FSC/SSC patterns were correlated with different clinical and biological characteristics of AML patients.
\end{abstract}

Results-No significant associations were detected in relation to the clinical and haematological disease characteristics and the prognosis of these patients. By contrast there was a significant correlation between the FSC/SSC pattern of the AML blast cells and the FAB classification. An increased reactivity for the antigens associated with myeloid differentiation such as CD13, CD33, CD11b, CD15, CD14, CD4, CD56, and/or CD16 was detected among cases showing a mature FSC/SSC pattern $(3,4$, and 5$)$, both in the whole series and even within each of the FAB AML subtypes. By contrast, the reactivity for the CD34 precursor cell associated antigen was higher among those cases displaying an immature FSC/SSC pattern, this being observed even within each FAB subgroup.

Conclusions-The FSC/SSC pattern distribution of AML blast cells not only provides an additional objective and reproductible system for the classification of these leukaemias but it may also represent a connection between the FAB morphological groups and the immunophenotypic classification of AML patients. (f Clin Pathol 1995;48:456-462)

Keywords: Acute myeloblastic leukaemia, light scatter, immunophenotype, morphology.
The French-American-British Cooperative Group (FAB) classification, ${ }^{12}$ which is based on both morphological and cytochemical criteria, is the most widely accepted and used classification for the acute leukaemias. However, this classification has received criticism from several sources, mainly because of discrepancies among different observers. ${ }^{3-6}$ This has led other groups to propose alternative classifications, some of which include cytogenetic and immunophenotypic criteria. ${ }^{7-9}$

At present, immunophenotypic studies on patients with acute myeloblastic leukaemia (AML) frequently combine the use of monoclonal antibodies and flow cytometry. Two types of index can be measured: that related to the light scatter, and that associated with the presence of fluorochromes in a cell. ${ }^{1011}$ Measurements of the low angle forward light scatter (FSC) and the orthogonal light scatter (SSC) have been shown to provide information about cell size, asymmetry, and viability, as well as on the internal complexity of the cell. ${ }^{1011}$ Thus the combination of these two light scatter indices allows the identification of different leucocyte subpopulations in both peripheral blood and bone marrow. ${ }^{10-12}$ Analysis of AML blast cells combining monoclonal antibodies and flow cytometry may therefore provide information not only on the phenotypic characteristics of the blast cells but also on their FSC/SSC features. Up to now no account has been taken of the distribution pattern of AML blast cells according to their light scatter properties in most immunophenotypical studies on AML patients. This is probably because it has been shown that there is no absolute correlation between this morphological information obtained using flow cytometry and the FAB classification. ${ }^{12}$

The aim of the present study was to analyse the FSC/SSC distribution of AML blast cells in order to assess whether or not it correlates with their morphology, immunophenotype, and clinical and biological disease characteristics.

\section{Methods}

PATIENTS

One hundred and seventy one untreated patients with de novo AML diagnosed according to the FAB criteria ${ }^{12}$ were included in the study.

Patients under 65 years old and older patients in otherwise good physical health were treated 
according to a standard protocol which included daunorubicin $\left(60 \mathrm{mg} / \mathrm{m}^{2}\right.$ for three days) and Ara-C ( $200 \mathrm{mg} / \mathrm{m}^{2}$ for seven days). The criteria of Ellison $e t$ al $^{13}$ were used to ascertain the achievement of complete remission.

\section{IMMUNOLOGICAL PHENOTYPE}

For the immunophenotypic characterisation of the AML blast cells a panel of monoclonal antibodies (Mab) was used: the specificity of these $\mathrm{Mab}$ has been described elsewhere. ${ }^{71415}$ This panel included markers against the different myeloid lineages, as well as several Mab for precursor cells and other markers directed against lymphoid $\mathrm{T}, \mathrm{B}$, and natural killer (NK) cell linages. All cases were tested for at least one specific Mab for all the different cell lineages, using double and triple staining procedures. The Mab used were: FMC56 (CD9); 3C5, HPCA-1, HPCA-2 (CD34); anti-HLADR; My7, Leu M7 (CD13); My9, Leu M9 (CD33); Leu 15 (CD11b); Leu M1 (CD15), Leu M3 (CD14); anti-glycophorin A; antitransferrin receptor (CD71); anti-GPIIIa (CD61); J15 (CD41); AN51, FMC25 (CD42); anti-TdT; Leu 12 (CD19); Leu 9 (CD7); Leu 5b (CD2); Leu 4 (CD3); Leu 3a (CD4); Leu 2 (CD8); Leu 19 (CD56); Leu 11c (CD16).
Analysis of cell reactivity with the different Mab combinations was performed on an FACScan flow cytometer (Becton Dickinson), equipped with an argon ion laser tuned at $488 \mathrm{~nm}$ and $15 \mathrm{~mW}$. Results were analysed for at least 4000 cells per test, using the LYSIS-II and PAINT-A-GATE software programs (Becton Dickinson). An antigen was considered to be positive when at least $15 \%$ of the blast cells expressed this marker. Erythroblasts were excluded from the analysis gate used for the M6 leukaemia blast cells.

\section{FSC/SSC PATTERNS}

In all patients included in the present study the FSC/SSC distribution pattern of the blast cells was recorded and analysed. Five different FSC/SSC patterns were established upon taking into account the localisation of the residual T lymphocytes in the FSC/SSC dot plot as an internal biological standard (fig 1), where the $\mathrm{T}$ lymphocytes are represented by red dots. In all groups, blast cells usually displayed a homogeneous distribution with respect to the FSC/SSC patterns observed in both normal peripheral blood and bone marrow samples. In pattern 1, blast cells displayed a low FSC and SSC, with a distribution that overlapped that
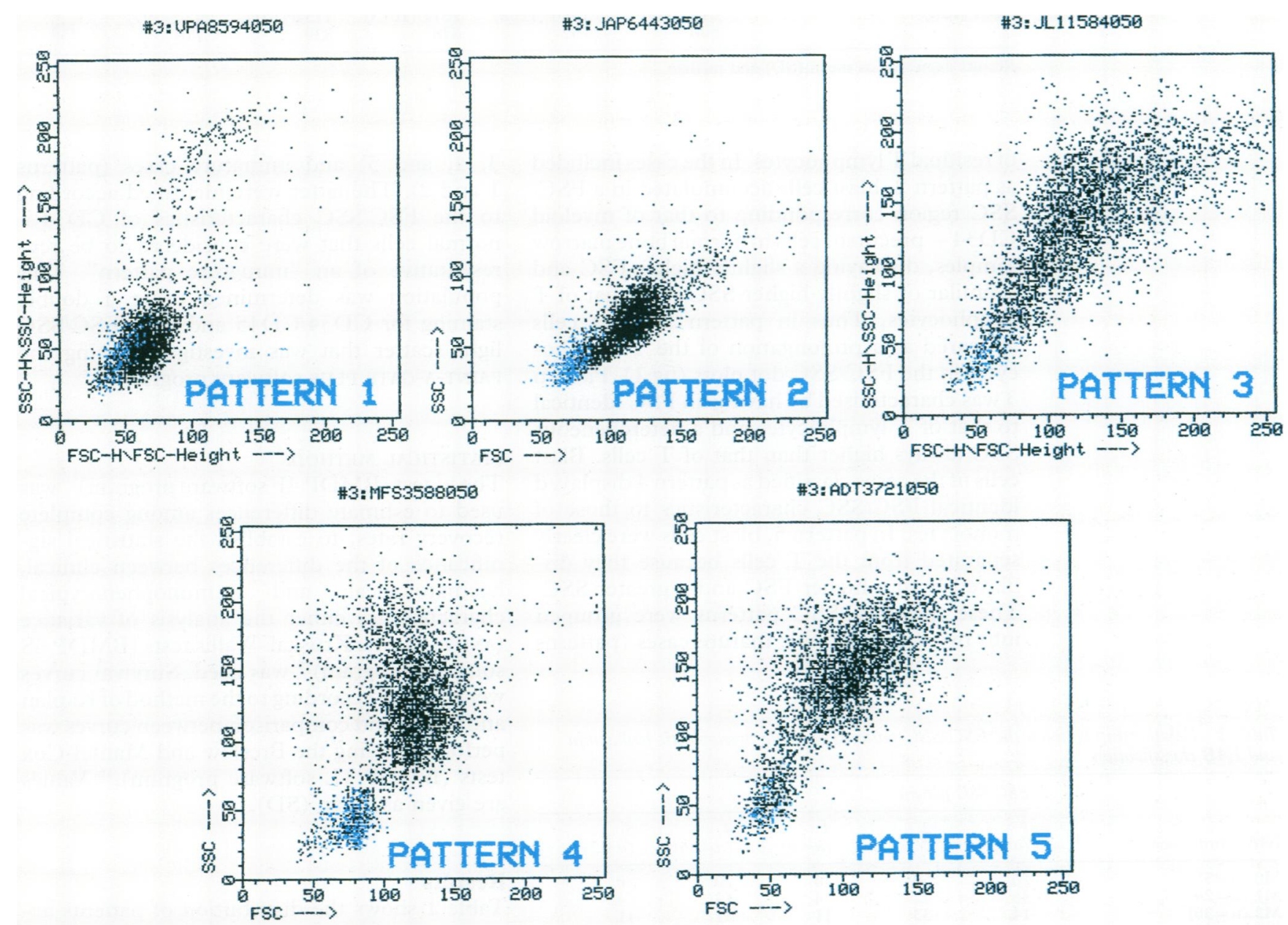

Blue dots: T lymphocytes

Figure 1 Classification of light scatter patterns in acute myeloblastic leukaemia. 
Table 1 Clinical characteristics of acute myeloblastic leukaemia cases according to the FSC/SSC pattern of blast cells

\begin{tabular}{|c|c|c|c|c|c|c|}
\hline & \multicolumn{5}{|c|}{ FSC/SSC pattern } & \multirow[b]{2}{*}{$p$} \\
\hline & $\begin{array}{l}1 \\
(n=34)\end{array}$ & $\begin{array}{l}2 \\
(n=43)\end{array}$ & $\begin{array}{l}3 \\
(n=9)\end{array}$ & $\begin{array}{l}4 \\
(n=56)\end{array}$ & $\begin{array}{l}5 \\
(n=29)\end{array}$ & \\
\hline $\begin{array}{ll}\text { Sex } & M \\
& F\end{array}$ & $\begin{array}{l}62 \\
38\end{array}$ & $\begin{array}{l}66 \\
34\end{array}$ & $\begin{array}{l}60 \\
40\end{array}$ & $\begin{array}{l}43 \\
57\end{array}$ & $\begin{array}{l}59 \\
41\end{array}$ & NS \\
\hline Age* & $62(13), 62$ & $61(20), 64$ & $57(23), 56$ & $56(19), 59$ & $59(16), 61$ & NS \\
\hline Hepatomegaly & 13 & 26 & 44 & 42 & 27 & $0 \cdot 04$ \\
\hline Splenomegaly & 13 & 26 & 0 & 27 & 17 & NS \\
\hline Lymph nodes & 16 & 22 & 44 & 28 & 24 & NS \\
\hline Other infiltration & 7 & 8 & 22 & 20 & 26 & NS \\
\hline
\end{tabular}

Results expressed as percentages. *Mean (SD), median.

Table 2 Biological features of acute myeloblastic leukaemia cases according to the FSC/SSC pattern of blast cells

\begin{tabular}{|c|c|c|c|c|c|c|}
\hline & \multicolumn{5}{|c|}{ FSC/SSC pattern } & \multirow[b]{2}{*}{$p$} \\
\hline & $\begin{array}{l}1 \\
(n=34)\end{array}$ & $\begin{array}{l}2 \\
(n=43)\end{array}$ & $\begin{array}{l}3 \\
(n=9)\end{array}$ & $\begin{array}{l}4 \\
(n=56)\end{array}$ & $\begin{array}{l}5 \\
(n=29)\end{array}$ & \\
\hline $\mathrm{Hb}(\mathrm{g} / \mathrm{dl})$ & $\begin{array}{l}7 \cdot 8(2 \cdot 1) \\
8 \cdot 1\end{array}$ & $\begin{array}{l}8 \cdot 5(2 \cdot 0) \\
8 \cdot 5\end{array}$ & $\begin{array}{l}9 \cdot 8(3 \cdot 0) \\
8 \cdot 7\end{array}$ & $\begin{array}{l}9 \cdot 1(2 \cdot 2) \\
9 \cdot 4\end{array}$ & $\begin{array}{l}8 \cdot 6(2 \cdot 3) \\
8 \cdot 1\end{array}$ & NS \\
\hline $\begin{array}{l}\text { Leucocytes } \\
\left(\times 10^{9} / 1\right)\end{array}$ & $\begin{array}{l}22(34) \\
37\end{array}$ & $\begin{array}{l}45(60) \\
21\end{array}$ & $\begin{array}{l}35(48) \\
18\end{array}$ & $\begin{array}{l}54(69) \\
30\end{array}$ & $\begin{array}{l}26(38) \\
12\end{array}$ & 0.02 \\
\hline $\begin{array}{l}\text { Platelets } \\
\left(\times 10^{9} / 1\right)\end{array}$ & $\begin{array}{l}54(46) \\
36\end{array}$ & $\begin{array}{l}57(42) \\
43\end{array}$ & $\begin{array}{l}68(58) \\
50\end{array}$ & $\begin{array}{l}65(58) \\
48\end{array}$ & $\begin{array}{l}48(43) \\
28\end{array}$ & NS \\
\hline $\begin{array}{l}\text { Peripheral blood blast } \\
\text { cells }(\%)\end{array}$ & $\begin{array}{l}54(35) \\
56\end{array}$ & $\begin{array}{l}61(28) \\
67\end{array}$ & $64(30)$ & $\begin{array}{l}64(27) \\
73\end{array}$ & $\begin{array}{l}49(29) \\
51\end{array}$ & NS \\
\hline $\begin{array}{l}\text { Bone marrow blast } \\
\text { cells }(\%)\end{array}$ & $\begin{array}{l}76(21) \\
83\end{array}$ & $\begin{array}{l}82(15) \\
87\end{array}$ & $\begin{array}{l}79(14) \\
83\end{array}$ & $\begin{array}{l}80(13) \\
82\end{array}$ & $\begin{array}{l}80(16) \\
85\end{array}$ & NS \\
\hline LDH (IU/l) & $\begin{array}{l}610(349) \\
500\end{array}$ & $\begin{array}{l}1380(1258) \\
752\end{array}$ & $\begin{array}{l}1071(1013) \\
648\end{array}$ & $\begin{array}{l}1134(1011) \\
839\end{array}$ & $\begin{array}{l}930(797) \\
770\end{array}$ & NS \\
\hline
\end{tabular}

Results expressed as mean (SD) and median.

of residual $\mathrm{T}$ lymphocytes. In the cases included as pattern 2, blast cells accumulated in a FSC/ SSC region corresponding to that of myeloid CD34 + precursor cells in normal bone marrow samples, displaying a slightly higher FSC and a similar or slightly higher SSC than that of $\mathrm{T}$ lymphocytes. Thus in pattern 2, blast cells appeared as a prolongation of the $\mathrm{T}$ lymphocytes in the FSC/SSC dot plots (fig 1). Pattern 3 was characterised by having an FSC identical to that of $\mathrm{T}$ lymphocytes and a heterogeneous SSC always higher than that of T cells. Blast cells of the cases classified as pattern 4 displayed identical FSC/SSC characteristics to those of monocytes. In pattern 5, blast cells were clearly separated from the $T$ cells because they displayed both a higher FSC and a greater SSC. These five FSC/SSC patterns were grouped into two major groups: mature cases (patterns

Table 3 Relationship between the FSC/SSC patterns of acute myeloblastic leukaemia and FAB classification

\begin{tabular}{|c|c|c|c|c|c|}
\hline \multirow[b]{2}{*}{$F A B$ classification } & \multicolumn{5}{|c|}{ FSC/SSC pattern } \\
\hline & $\begin{array}{l}1 \\
(n=34)\end{array}$ & $\begin{array}{l}2 \\
(n=43)\end{array}$ & $\begin{array}{l}3 \\
(n=9)\end{array}$ & $\begin{array}{l}4 \\
(n=56)\end{array}$ & $\begin{array}{l}5 \\
(n=29)\end{array}$ \\
\hline $\begin{array}{l}\text { M0 }(n=5) \\
\text { M1 }(n=24) \\
\text { M2 }(n=36) \\
\text { M3 }(n=25) \\
\text { M4 }(n=28) \\
\text { M5 }(n=43) \\
\text { M6 }(n=4) \\
\text { M7 }(n=4)\end{array}$ & $\begin{array}{r}20 \\
38 \\
14 \\
28 \\
0 \\
18 \\
50 \\
50\end{array}$ & $\begin{array}{r}60 \\
42 \\
33 \\
4 \\
28 \\
9 \\
25 \\
50\end{array}$ & $\begin{array}{r}0 \\
4 \\
11 \\
4 \\
11 \\
0 \\
0 \\
0\end{array}$ & $\begin{array}{r}20 \\
12 \\
31 \\
24 \\
46 \\
52 \\
0 \\
0\end{array}$ & $\begin{array}{r}0 \\
4 \\
11 \\
40 \\
14 \\
21 \\
25 \\
0\end{array}$ \\
\hline
\end{tabular}

Results expressed as percentages. $\mathrm{p}=0.0002$.
3, 4, and 5) and immature cases (patterns 1 and 2). The latter were identified according to the FSC/SSC characteristics of CD34+ normal cells that were considered to be representative of an "immature pattern". This population was determined using a double staining for CD34/CD45 and their FSC/SSC light scatter that was investigated using the PAINT-A-GATE PLUS software' program.

\section{STATISTICAL METHODS}

The $\chi^{2}$ test (BMDP $4 \mathrm{~F}$ software program $)^{16}$ was used to estimate differences among complete recovery rates; to establish the statistical significance of the differences between clinical, haematological, and immunophenotypical characteristics either the analysis of variance (ANOvA) or the Kruskal-Wallis tests (BMDP 3S software program $)^{16}$ was used. Survival curves were plotted according to the method of Kaplan and Meier and comparison between curves was performed using the Breslow and Mantel-Cox tests (BMDP $1 \mathrm{~L}$ software program). ${ }^{16}$ Values are given as mean (SD).

\section{Results}

Table 1 shows the distribution of patients according to the FSC/SSC pattern of their blast cells. The most frequent FSC/SSC pattern was number $4(33 \%)$, while pattern 3 was the least common one $(5 \%)$; similar frequencies were observed for pattern $1(20 \%)$, pattern $2(25 \%)$, 
Table 4 M1 acute myeloblastic leukaemia (AML) cases: phenotypic features of blast cells according to their FSCI SSC distribution pattern

\begin{tabular}{|c|c|c|c|}
\hline & $\underset{(n=19)}{\text { Immature }}(1$ and 2$)$ & $\underset{\substack{\text { Mature } \\
(n=5)}}{(3,4, \text { and } 5)}$ & $p$ \\
\hline CD33 & $\begin{array}{l}44(31) \\
79 \%\end{array}$ & $\begin{array}{l}73(19) \\
100 \%\end{array}$ & 0.05 \\
\hline CD13 & $\begin{array}{l}59(28) \\
95 \%\end{array}$ & $\begin{array}{l}79(19) \\
100 \%\end{array}$ & $0 \cdot 18$ \\
\hline CD11b & $\begin{array}{l}13(12) \\
41 \%\end{array}$ & $\begin{array}{l}33(20) \\
80 \%\end{array}$ & 0.05 \\
\hline CD15 & $\begin{array}{l}17(22) \\
37 \%\end{array}$ & $\begin{array}{l}25(16) \\
75 \%\end{array}$ & $0 \cdot 19$ \\
\hline CD14 & $\begin{array}{l}2(3) \\
0 \%\end{array}$ & $\begin{array}{l}5(2) \\
0 \%\end{array}$ & 0.04 \\
\hline CD4 & $\begin{array}{l}9(20) \\
22 \%\end{array}$ & $\begin{array}{l}33(36) \\
75 \%\end{array}$ & $0 \cdot 19$ \\
\hline CD56 & $\begin{array}{l}3(5) \\
8 \%\end{array}$ & $\stackrel{1}{0 \%}$ & NS \\
\hline CD16 & $\begin{array}{l}2(4) \\
8 \%\end{array}$ & $\begin{array}{l}6 \\
0 \%\end{array}$ & NS \\
\hline HLA-DR & $\begin{array}{l}62(29) \\
78 \%\end{array}$ & $\begin{array}{l}67(24) \\
100 \%\end{array}$ & NS \\
\hline CD34 & $\begin{array}{l}39(32) \\
72 \%\end{array}$ & $\begin{array}{c}7(9) \\
33 \%\end{array}$ & $0 \cdot 11$ \\
\hline
\end{tabular}

Results expressed as mean (SD) of positive blast cells and percentage of positive AML cases.

and pattern $5(17 \%)$. Upon grouping the FSC/ SSC patterns into mature and immature, almost half of the patients were included in each group ( $55 \%$ and $45 \%$, respectively). On the basis of "visual" criteria, three different observers analysed and classified the patients according to the FSC/SSC pattern of their blast cells; the concordance between them was $86 \%$.

The clinical and biological characteristics of the AML patients according to their FSC/SSC characteristics are shown in tables 1 and 2 . No major differences were observed between them, with the exception of a higher incidence of

Table 5 M2 acute myeloblastic leukaemia ( $A M L)$ cases: phenotypic features of blast cells according to their FSC/ SSC distribution pattern

\begin{tabular}{|c|c|c|c|}
\hline & $\begin{array}{l}\text { Immature (1 and 2) } \\
(n=17)\end{array}$ & $\begin{array}{l}\text { Mature } \\
(n=19)\end{array}(3,4$, and 5$)$ & $p$ \\
\hline CD33 & $\begin{array}{l}77(21) \\
94 \%\end{array}$ & $\begin{array}{l}78(26) \\
89 \%\end{array}$ & NS \\
\hline CD13 & $\begin{array}{l}55(30) \\
88 \%\end{array}$ & $\begin{array}{l}66(28) \\
89 \%\end{array}$ & NS \\
\hline CD11b & $\begin{array}{l}18(24) \\
44 \%\end{array}$ & $\begin{array}{l}24(30) \\
44 \%\end{array}$ & NS \\
\hline CD15 & $\begin{array}{l}23(25) \\
47 \%\end{array}$ & $\begin{array}{l}38(35) \\
63 \%\end{array}$ & NS \\
\hline CD14 & $\begin{array}{l}1(2) \\
0 \%\end{array}$ & $\begin{array}{l}12(26) \\
16 \%\end{array}$ & 0.05 \\
\hline CD4 & $\begin{array}{l}23(22) \\
56 \%\end{array}$ & $\begin{array}{l}39(33) \\
68 \%\end{array}$ & $0 \cdot 16$ \\
\hline CD56 & $\begin{array}{l}20(32) \\
38 \%\end{array}$ & $\begin{array}{l}25(34) \\
39 \%\end{array}$ & NS \\
\hline CD16 & $\begin{array}{l}1(0) \\
0 \%\end{array}$ & $\begin{array}{l}7(18) \\
11 \%\end{array}$ & NS \\
\hline HLA-DR & $\begin{array}{l}34(30) \\
65 \%\end{array}$ & $\begin{array}{l}60(33) \\
70 \%\end{array}$ & 0.02 \\
\hline CD34 & $\begin{array}{l}45(38) \\
64 \%\end{array}$ & $\begin{array}{l}26(35) \\
44 \%\end{array}$ & NS \\
\hline
\end{tabular}

Results expressed as mean (SD) of positive blast cells and percentage of positive AML cases.
Table 6 M3 acute myeloblastic leukaemia (AML) cases: phenotypic features of blast cells according to their FSCI SSC distribution pattern

\begin{tabular}{|c|c|c|c|}
\hline & $\begin{array}{l}\text { Immature (1 and 2) } \\
(n=8)\end{array}$ & $\begin{array}{l}\text { Mature }(3,4, \text { and } 5) \\
(n=17)\end{array}$ & $p$ \\
\hline CD33 & $\begin{array}{l}84(9) \\
100 \%\end{array}$ & $\begin{array}{l}90(7) \\
100 \%\end{array}$ & 0.06 \\
\hline CD13 & $\begin{array}{l}69(17) \\
100 \%\end{array}$ & $\begin{array}{l}85(16) \\
93 \%\end{array}$ & 0.01 \\
\hline CD11b & $\begin{array}{l}10(21) \\
13 \%\end{array}$ & $\begin{array}{l}9(17) \\
13 \%\end{array}$ & NS \\
\hline CD15 & $\begin{array}{l}29(25) \\
62 \%\end{array}$ & $\begin{array}{l}21(27) \\
41 \%\end{array}$ & NS \\
\hline CD14 & $\begin{array}{l}2(3) \\
0 \%\end{array}$ & $\begin{array}{l}2(8) \\
0 \%\end{array}$ & NS \\
\hline $\mathrm{CD} 4$ & $\begin{array}{l}27(31) \\
50 \%\end{array}$ & $\begin{array}{l}21(25) \\
43 \%\end{array}$ & NS \\
\hline CD56 & $\begin{array}{l}17(35) \\
20 \%\end{array}$ & $\begin{array}{l}9(24) \\
10 \%\end{array}$ & NS \\
\hline CD16 & $\begin{array}{l}0(0) \\
0 \%\end{array}$ & $\begin{array}{l}0(0) \\
0 \%\end{array}$ & NS \\
\hline HLA-DR & $\begin{array}{l}15(24) \\
25 \%\end{array}$ & $\begin{array}{l}9(15) \\
18 \%\end{array}$ & NS \\
\hline CD34 & $\begin{array}{l}27(35) \\
37 \%\end{array}$ & $\begin{array}{l}13(23) \\
22 \%\end{array}$ & NS \\
\hline
\end{tabular}

Results expressed as mean (SD) of positive blast cells and percentage of positive AML cases.

hepatomegaly in those cases displaying either pattern 3 or pattern $4(\mathrm{p}=0.04)$ and a greater peripheral blood white cell count in pattern 4 patients $(p=0.02)$.

Upon comparing the distribution of the different FAB morphological subgroups in each of the FSC/SSC patterns, a statistically significant correlation $(p=0.0002)$ was detected between the two classifications (table 3). Eighty percent of the M0 and M1 AML cases displayed immature FSC/SSC patterns (patterns 1 and 2) while $M 2$ and $M 3$ cases showed a heterogeneous distribution, $40 \%$ of the M3

Table 7 M4 acute myeloblastic leukaemia (AML) cases: phenotypic features of blast cells according to their FSCI SSC distribution pattern

\begin{tabular}{|c|c|c|c|}
\hline & $\underset{(n=8)}{\text { Immature }}(2)$ & $\begin{array}{l}\text { Mature } \\
(n=20)\end{array}(3,4$, and 5) & $p$ \\
\hline CD33 & $\begin{array}{l}64(32) \\
87 \%\end{array}$ & $\begin{array}{l}74(24) \\
95 \%\end{array}$ & NS \\
\hline $\mathrm{CD} 13$ & $\begin{array}{l}78(15) \\
100 \%\end{array}$ & $\begin{array}{l}75(16) \\
100 \%\end{array}$ & NS \\
\hline $\mathrm{CD} 11 \mathrm{~b}$ & $\begin{array}{l}18(24) \\
33 \%\end{array}$ & $\begin{array}{l}48(34) \\
83 \%\end{array}$ & 0.03 \\
\hline CD15 & $\begin{array}{l}19(19) \\
50 \%\end{array}$ & $\begin{array}{l}45(35) \\
65 \%\end{array}$ & 0.08 \\
\hline CD14 & $\begin{array}{l}5(5) \\
13 \%\end{array}$ & $\begin{array}{l}33(31) \\
60 \%\end{array}$ & 0.03 \\
\hline $\mathrm{CD} 4$ & $\begin{array}{l}26(27) \\
57 \%\end{array}$ & $\begin{array}{l}46(36) \\
75 \%\end{array}$ & $0 \cdot 19$ \\
\hline CD56 & $\begin{array}{l}0(0) \\
0 \%\end{array}$ & $\begin{array}{l}39(32) \\
70 \%\end{array}$ & 0.005 \\
\hline CD16 & $\begin{array}{l}1(2) \\
0 \%\end{array}$ & $\begin{array}{l}17(27) \\
30 \%\end{array}$ & $0 \cdot 10$ \\
\hline HLA-DR & $\begin{array}{l}66(22) \\
100 \%\end{array}$ & $\begin{array}{l}67(21) \\
100 \%\end{array}$ & NS \\
\hline CD34 & $\begin{array}{l}50(32) \\
80 \%\end{array}$ & $\begin{array}{l}26(26) \\
60 \%\end{array}$ & $0 \cdot 11$ \\
\hline
\end{tabular}

Results expressed as mean (SD) of positive blast cells and percentage of positive AML cases. 
Table 8 M5 acute myeloblastic leukaemia $(A M L)$ cases. phenotypic features of blast cells according to their FSC/ SSC distribution pattern

\begin{tabular}{|c|c|c|c|}
\hline & $\underset{(n=12)}{\text { Immature }}(1$ and 2$)$ & $\begin{array}{l}\text { Mature } \\
(n=31)\end{array}$ & $p$ \\
\hline CD33 & $\begin{array}{l}42(31) \\
75 \%\end{array}$ & $\begin{array}{l}78(29) \\
94 \%\end{array}$ & 0.0009 \\
\hline $\mathrm{CD} 13$ & $\begin{array}{l}66(17) \\
92 \%\end{array}$ & $\begin{array}{l}72(32) \\
84 \%\end{array}$ & $0 \cdot 10$ \\
\hline CD11b & $\begin{array}{l}25(23) \\
64 \%\end{array}$ & $\begin{array}{l}61(36) \\
79 \%\end{array}$ & 0.01 \\
\hline CD15 & $\begin{array}{l}15(27) \\
27 \%\end{array}$ & $\begin{array}{l}51(39) \\
67 \%\end{array}$ & 0.01 \\
\hline CD14 & $\begin{array}{l}17(32) \\
17 \%\end{array}$ & $\begin{array}{l}34(32) \\
58 \%\end{array}$ & $0 \cdot 23$ \\
\hline $\mathrm{CD} 4$ & $\begin{array}{l}35(27) \\
75 \%\end{array}$ & $\begin{array}{l}60(30) \\
90 \%\end{array}$ & 0.006 \\
\hline CD56 & $\begin{array}{l}26(39) \\
40 \%\end{array}$ & $\begin{array}{l}39(39) \\
60 \%\end{array}$ & $0 \cdot 28$ \\
\hline CD16 & $\begin{array}{l}0(0) \\
0 \%\end{array}$ & $\begin{array}{l}29(25) \\
68 \%\end{array}$ & 0.002 \\
\hline HLA-DR & $\begin{array}{l}80(18) \\
100 \%\end{array}$ & $\begin{array}{l}79(24) \\
91 \%\end{array}$ & NS \\
\hline CD34 & $\begin{array}{l}49(32) \\
80 \%\end{array}$ & $\begin{array}{l}18(22) \\
38 \%\end{array}$ & 0.09 \\
\hline
\end{tabular}

Results expressed as mean (SD) of positive blast cells and percentage of positive AML cases.

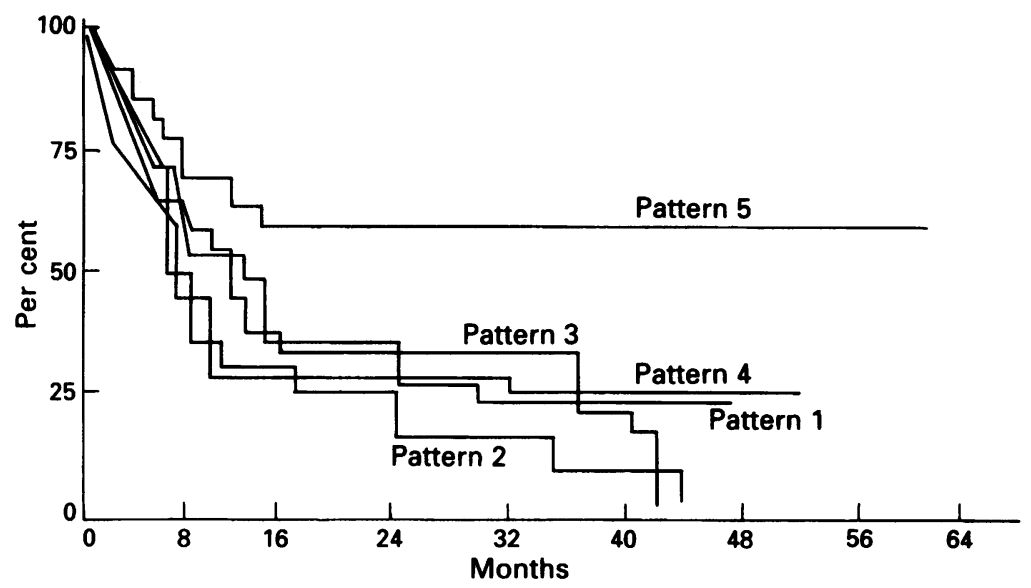

Figure 2 Survival curves of the different FSC/SSC pattern groups of AML patients. Mantel-Cox $p=0.49 ;$ Breslow $p=0.94$.

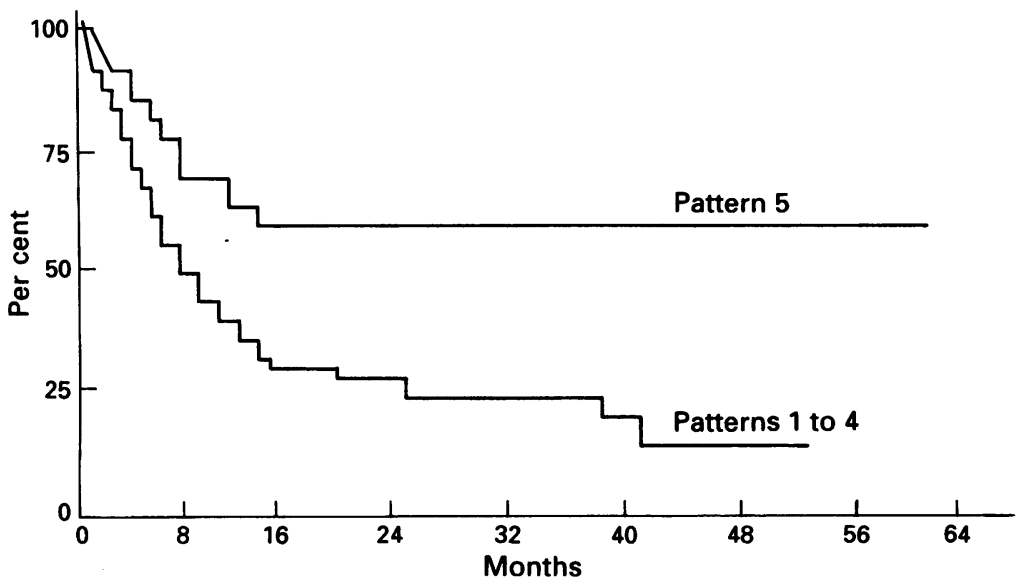

Figure 3 Survival curves of the FSC/SSC pattern $5 v$ the rest in AML patients. Mantel-Cox $p=0.43 ;$ Breslow $p=0.68$. leukaemias corresponding to the mature pattern 5. Forty six percent of the M4 patients, $52 \%$ of all M5 patients, and $81 \%$ of the M5b patients were included in pattern 4 . Moreover, $73 \%$ of the M4 patients and $72 \%$ of the M5 patients had mature FSC/SSC patterns (patterns 3, 4, and 5). By contrast, most of the M6 (75\%) and all of the M7 AML cases displayed either pattern 1 or pattern 2.

We also analysed whether or not the FSC/ SSC pattern of blast cells within each FAB subtype correlated with cell differentiation, as shown by the expression of distinct cell surface markers. Upon grouping our patients into immature and mature FSC/SSC cases, important phenotypic differences were detected for each morphological subtype; these are shown in tables 4-8. Both $M 6$ and M7 leukaemias were excluded from the analysis since in the present series few cases were included in either of these FAB subtypes. Statistically significant differences between $M 1$ cases with immature or mature FSC/SSC patterns were detected for antigens CD33 (44(SD 31) v 73(19); $\mathrm{p}=0.05)$, CD11b (13(12) v 33(20); $\mathrm{p}=0.05)$, and CD14 (2(3) $v 6(2) ; \mathrm{p}=0.04$ ) (table 4). Regarding M2 leukaemias, a lower expression of antigens CD14 (1(2) v 12(26); $\mathrm{p}=0.05)$ and HLA-DR (34(30) $v$ 26(35); $\mathrm{p}=0.02)$ was detected in patients with an immature FSC/SSC pattern (table 5). In the M3 AML cases with an immature FSC/SSC pattern, a lower reactivity for the CD13 antigen (69(17) $v 85(16) ; \mathrm{p}=0.01)$ was detected (table 6). In addition, M4 cases with an immature FSC/SSC pattern showed a lower reactivity for antigens CD11b (18(24) $v$ 48(34); $\mathrm{p}=0.03), \mathrm{CD} 14$ (5(5) v 33(31); $\mathrm{p}=$ $0.03)$, and CD56 (0(0) v 39(32); $\mathrm{p}=0.005)$ (table 7). Likewise, AML patients classified as M5 leukaemias with an immature light scatter pattern had a significantly lower reactivity for antigens CD33 (42(31) v 78(29); $\mathrm{p}=0.0009)$, CD11b (25(23) v 61(36); $\mathrm{p}=0.01), \mathrm{CD} 15$ (15(27) $v$ 61(39); $\mathrm{p}=0.01), \mathrm{CD} 4$ (35(27) $v$ $60(30) ; \mathrm{p}=0.006)$, and CD16 (0(0) v 29(25); $\mathrm{p}=0.002$ ) (table 8 ). No statistically significant differences were detected for the expression of other antigens analysed, although the expression of the CD34 antigen was always higher in the cases in which cells displayed an immature FSC/SSC pattern (tables 4-8). Regarding the analysis of the prognostic impact of the FSC/SSC pattern of the leukaemic blast cells, no statistically significant differences were detected with respect to either the complete remission rate (pattern 1: 74\%; pattern 2: $70 \%$; pattern 3: $80 \%$; pattern $4: 70 \%$; pattern 5: $80 \%$ ) or survival, although the patients with FSC/SSC pattern 5 had a slightly better outcome (figs 2 and 3 ).

\section{Discussion}

The morphological classification of AML proposed by the FAB group is limited to subjective interpretation, and the degree of agreement obtained between different observers, even experts, is usually lower than $70 \% .^{3561718}$ These problems have led several groups to propose alternative classifications, incorporating other 
aspects, such as the morphological, immunological, and cytogenetic (MIC) ${ }^{9}$ and immunophenotypic ${ }^{7}$ classifications of AML.

Flow cytometry provides information on both the immunophenotype and the morphology associated characteristics of blast cells, as assessed by their FSC/SSC properties. ${ }^{111}$ To the best of our knowledge, there has only been one attempt to group AML patients according to the light scatter properties of the leukaemic cells. ${ }^{12}$ In that study AML cases were divided into nine different categories that were grouped into three different FSC/SSC patterns, and their correlation with the FAB classification was analysed.

In the present paper the light scatter characteristics of 171 newly diagnosed AML patients were analysed. In contrast to normal peripheral blood or bone marrow samples, leukaemic specimens showed quite a homogeneous FSC/SSC distribution. This is related to the monomorphic morphology displayed by leukaemic compared with normal samples. When examining the FSC/SSC distribution of normal bone marrow cells, ${ }^{19}$ a correlation between the light scatter properties of the leukaemic blast cells and that of normal myeloid cells can be established. Five different FSC/SSC patterns were determined by taking the FSC/SSC of the residual T lymphocytes as a reference. These five patterns could be grouped into two major categories: (1) immature patterns: cases displaying FSC/SSC patterns that overlap those of normal myeloid precursor cells (patterns 1 and 2); and (2) mature patterns: those in which leukaemic cells accumulate in regions corresponding to more mature monocytic (pattern 4) or granulocytic cells (patterns 3, 4, and 5). The existence of a clear cutoff between $\mathrm{T}$ lymphocytes and blast cells would allow a good discrimination between the two groups of patients. Interestingly, a high reproducibility ( $86 \%$ ) was found in the present study for this classification, even when only a subjective interpretation of the FSC/ SSC dot plots was performed and the values of the arbitrary unit (channel) for these cell populations were not considered.

Upon grouping the AML patients according to the FSC/SSC pattern of their blast cells no major differences were observed regarding the clinical and biological disease characteristics of the different groups, with the exception of higher mean peripheral blood white cell counts in pattern 4, and a high frequency of hepatomegaly in patterns 3 and 4 . This is probably because of the higher incidence of monocytic leukaemias detected in this group. In addition, no significant differences in prognosis were detected among the different groups, although there was a slightly better survival rate in patients displaying pattern 5 . This was probably related to the high incidence of M3 leukaemias within this FSC/SSC pattern. By contrast, there was a significant correlation between the FSC/ SSC pattern of the AML blast cells and the FAB morphology classification. In this sense, the morphologically undifferentiated cases (MO and $M 1$ cases) were associated with an immature FSC/SSC pattern, while cases dis- playing more mature morphological characteristics (M2, M3, M4, and M5 leukaemias) showed a higher incidence of mature FSC/SSC patterns. However, several FSC/SSC patterns can be found in each FAB morphological subtype. The present results indicate that the FSC/ SSC pattern of blast cells to a large extent reflects the morphological and immunological differentiation associated features of myeloid cells. Accordingly upon analysing the immunological characteristics of the immature versus the mature FSC/SSC patterns, our results showed that this classification of AML cases largely reflects cell differentiation along the monocytic and granulocytic cell lineages and may explain some of the discrepancies detected among the morphological and phenotypic characteristics of AML blast cells. In this sense, an increased reactivity for the antigens associated with myeloid differentiation, such as CD13, CD33, CD11b, CD15, CD14, CD4, CD56, and CD16, was detected among cases showing a mature FSC/SSC pattern, both in the whole series and even within each of the AML FAB subtypes. By contrast, the reactivity for the CD34 precursor cell associated antigen, even within each FAB subgroup, was higher among the cases with an immature FSC/SSC pattern.

In summary, our results indicate that the FSC/SSC pattern distribution of AML blast cells provides not only additional objective information for the classification of these leukaemias but may also represent the connection between the FAB morphological groups and the immunophenotypic classification of AML patients.

This work was supported by institutional grant from the Comisión Interministerial de Ciencia y Tecnología (CICYT SAF 92/0041)

1 Bennett JM, Catovsky D, Daniel MT, Flandrin G, Galton DAG, Gralnick HR, et al. (FAB group). Criteria for the diagnosis of acute leukemia of megakaryocyte lineage. Ann Iintern Med 1985;103:626-9.

2 Bennett JM, Catovsky D, Daniel MT, Flandrin G, Galton DAG, Gralnick HR, et al. Proposed revised criteria for the classification of acute myeloid leukemia: a report of the French-American-British Cooperative Group. Ann Intern Med 1985;103:620-4.

3 Argyle JC, Benjamin DR, Lampking B, Hammond D. Acute nonlymphocytic leukemia of childhood. Inter-observer variability and problems in the use of the FAB classification. Cancer 1989;63:295-301.

4 Bain BJ. Acute leukaemia. In: Leukaemia diagnosis. A guide to the FAB classification. London: Gower Medical Publishing, 1990:1-43.

5 Dick FR, Armitage JO, Burns CP. Diagnostic concurrence in the subclassification of adult acute leukemia using FrenchAmerican-British criteria. Cancer 1982;49:916-20.

6 Head DR, Cerezo L, Savage RA, Craven CM, Bickers JN, Hartsock R, et al. Institutional performance in application of FAB classification of acute leukemia. The Southwes Oncology Group experience. Cancer 1985;55:1979-86.

7 San Miguel JF, González M, Cañizo MC, Anta JP, Zola H, López Borrasca A. Surface marker analysis in acute myeloid leukaemia and correlation with FAB classification Br f Haematol 1986;64:547-60.

8 San Miguel JF, Ojeda E, González M, Orfao A, Cañizo MC, Sánchez I, et al. Prognostic value of immunological markers in acute myeloid leukemia. Leukemia 1989;3 108-11.

9 Second MIC Cooperative Study Group. Morphologic, immunologic and cytogenetic (MIC) working classification of the acut

10 Orfao A, Ruiz Argüelles A. Citometría de flujo y su apliOrfao A, Ruiz Argüelles A. Citometria de flujo y su apli-
cación en hematologia. In: López Borrasca A, Arocha cación en hematologia. In: López Borrasca A, Arocha
Pirango CL, Campos Guerra C, Parreira A, Pavlosky S, Puiz-Argüelles G, San Miguel JF, eds. Enciclopedia de hematologia iberoamericana, vol 1. Salamanca: Ediciones Universidad de Salamanca, 1992:161-75.

11 Orfao A, González M, Ciudad J, López-Berges C, López A, San Miguel JF, et al. Aplicaciones de la citometria de 
flujo en el diagnóstico Hematológico. Biol Clin Hematol 1992;14:193-203.

12 Terstappen LW, Könemann S, Safford M, Loken MR Zurlutter K, Büchner T, et al. Flow cytometric characterization of acute myeloid leukemia Part 1. Significance of light scattering properties. Leukemia 1991;5:315-21.

13 Ellison RR, Holland JF, Weil M, et al. Arabinosyl cytosine; a useful agent in the treatment of acute leukemia in adults. Blood 1968;32:507-23.

14 San Miguel JF, Hernández JM, González-Sarmiento $R$, González M, Sánchez I, Orfao A, et al. Acute leukemia after primary myelodysplastic syndrome: immunophenotypic, genotypic and clinical characteristics. Blood 1991;78:768-72.

15 Vidriales MB, Orfao A, González M, Hernández JM, LópezBerges MC, Garcia MA, et al. Expression of NK and lymphoid-associated antigens in blast cells of acute myeloblastic leukemia. Leukemia 1993;7:2026-9.
16 Dixon WJ. (Biomedical-Data Package): Statistical software. Berkeley, California: University of California, 1983.

17 Castoldi GL. Reliability of conventional cytological classification: experience of GIMEMA and EORTC. Proceedings of the XII Meeting of the International Society of Hematology (European and African division), Vienna, 1993:16 (Abstract).

18 Terstappen LW, Safford M, Unterhalt M, Könemann S Zurlutter K, Piechotka K, et al. Flow cytometric characterization of acute myeloid leukemia: IV. Comparison to the differentiation pathway of normal hematopoietic progenitors cells. Leukemia 1992;6:993-1000.

19 Loken MR, Civin CI, Shah VO, Fackler MF, Segers-Nolten I, Terstappen LW. Flow cytometric characterization of erythroid, lymphoid and monomyeloid lineages in norma human bone marrow. In: Laerum OD, Bjerknes R, eds. Flow cytometry in hematology. London: Academic Press, 1992:31-40. 